\title{
Patient classification in rehabilitation as a basis for performance-related payments
}

\author{
G Neubauer $^{1 *}$, J Ranneberg ${ }^{2}$, A Wick $^{3}$ \\ From 26th Patient Classification Systems International (PCSI) Working Conference \\ Munich, Germany. 15-18 September 2010
}

\section{Introduction}

Since Germany introduced a comprehensive system for its acute-care sector, post-acute rehabilitation is under economic pressure. Patients are referred earlier and less healed to rehabilitation clinics. In addition, "payers" are not willing to pay more for post-acute rehabilitation. This situation requires an adequate classification system for rehab patients.

\section{Methods}

There are several proposals to solve the problem described in Germany. One approach is the "patient classification system for rehab patients" which was developed by the Institute of Health-Economics (IfG). It will be described in the following section.

Following the logic of DRG, the system starts with major indication fields like musculoskeletal disorder, neurology, etc. In the next step, with the assistance of rehabilitation physicians, we defined basic rehabilitation treatment groups (RTGs/RBGs) for each indication field. As a result, we found 7 basic groups and 12 severity groups for orthopaedics, and 10 basic groups and 13 severity groups for cardiology.

\section{Results}

In cooperation with 10 rehab clinics, we calculated the average costs for each RTG. By grouping, we found out a coefficient of determination $\left(R^{\wedge} 2\right)$ of 0.4 . By defining the various subgroups via the "Barthel-Index", we were able to improve the coefficient of determination $\left(R^{\wedge} 2\right)$ by a further 5 percentage points.

\section{Conclusions}

At the conference we would like to discuss our results, methods and how to establish a performance-based

${ }^{1}$ IfG München, München, Germany

Full list of author information is available at the end of the article compensation system for our RTGs. Moreover, we would like to think about how RTGs and DRGs can be assembled to determine complex lump-sum rates ("Komplexpauschalen"). Another question to be discussed is how health insurance funds can be included in this process.

Author details

${ }^{1}$ IfG München, München, Germany. ${ }^{2}$ BKK Landesverband Bayern, München, Germany. ${ }^{3}$ Universität der BW München, Neubiberg, Germany.

Published: 6 October 2010

doi:10.1186/1472-6963-10-S2-A22

Cite this article as: Neubauer et al:: Patient classification in rehabilitation as a basis for performance-related payments. BMC Health Services Research 2010 10(Suppl 2):A22.

\section{Submit your next manuscript to BioMed Central and take full advantage of: \\ - Convenient online submission \\ - Thorough peer review \\ - No space constraints or color figure charges \\ - Immediate publication on acceptance \\ - Inclusion in PubMed, CAS, Scopus and Google Scholar \\ - Research which is freely available for redistribution

